\title{
Caustic Injury
}

National Cancer Institute

\section{Source}

National Cancer Institute. Caustic Injury. NCI Thesaurus. Code C35622.

Tissue corrosion or chemical burn. 